\title{
Serum Proteins and Antibody Activity in Human Nasal Secretions *
}

\author{
Jack S. Remington, Kenneth L. Vosti, Arthur Lietze, and \\ A. LEONARD Zi M MERMAN \\ (From the Division of Allergy, Immunology, and Infectious Diseases, Palo Alto Medical Re- \\ search Foundation, the Department of Medicine, Stanford University School of \\ Medicine, and the Department of Otolaryngology, Palo Alto Medical \\ Clinic, Palo Alto, Calif.)
}

The presence of serum proteins and antibody activity against a variety of bacteria and viruses has been described in certain human secretions and excretions : vaginal $(2,3)$, salivary $(4,5)$, intestinal $(6)$, prostatic $(7)$, urine $(8,9)$, and feces $(10,11)$. The capacity of human nasal secretions to inactivate viruses was first described by Amoss and Taylor in 1917 (12) and confirmed by Howitt in 1937 (13). In 1939 Burnet, Lush, and Jackson. (14) published the results of their studies with a number of viruses including influenza and poliomyelitis. These authors were doubtful whether the protocols of Amoss and Taylor and of Howitt were sufficient to justify the conclusion that any specific viricidal agent was concerned and concluded from their own data that the inactivating agent is most likely an enzyme. In 1941 Francis and Brightman (15) reported the development or increase in the viral inactivating capacity of nasal secretions of individuals in the acute and convalescent stages of influenza and later, the enhanced capacity of nasal secretions to inactivate the virus when vaccination with influenza virus induces a significant increase in titer of neutralizing antibodies in the blood (16). In 1948 Bell (17), working with polio virus, published additional evidence that the neutralizing substance is specific antibody, although in two instances in which the nasal secretions neutralized the virus,

\footnotetext{
* Submitted for publication February 19, 1964; accepted April 21, 1964.

Presented in part before the Western Society. for Clinical Research on January 30, 1964 (1).

These studies were principally supported by a grant from the Hartford Foundation, New York. They were assisted also by a grant from the Gustavus and Louise Pfeiffer Research Foundation, New York, and grant AI-05878 from the National Institute of Allergy and Infectious Diseases.
}

the corresponding serum did not. The over-all results of the studies cited above suggest that neutralization of virus by nasal secretions is due to antibody and that such antibody may be of importance in host resistance to those agents.

If viral neutralizing antibody is present on the surface of the nasal mucosa, other antibodies may be present as well. The present studies, undertaken to determine the nature of the proteins found in nasal secretions, have revealed $\gamma$-globulins in the nasal secretions of all normal and allergic individuals examined. Reagenic antibody activity was found in the nasal secretions of allergic individuals and antibacterial antibodies in the nasal secretions of normal volunteers.

\section{Methods}

Human volunteers, from whom nasal secretions were obtained, were divided into two categories: normal and allergic (defined by a history of nasal allergy and skin testing). The allergic persons did not have signs or symptoms of clinical allergy at the time the secretions were collected. The technique employed for collection of the secretions was similar to that used by Anderson, Riff, and Jackson (18), who allowed $5 \mathrm{ml}$ of distilled water to run into each nostril while the subject held his head in hyperextension with the tongue elevated and the glottis closed. Washings were collected in a sterile Petri dish held under the nose as the head was tipped forward. However, in the present study $0.15 \mathrm{M} \mathrm{NaCl}$ was employed rather than distilled water because the latter was found to be irritating. Results of immunodiffusion studies with nasal secretions collected using $0.15 \mathrm{M} \mathrm{NaCl}$ were the same as those with secretions collected using distilled water. The washings were dialyzed in Visking tubing ( $\frac{1}{4}$ inch) for 24 hours against distilled water and lyophilized, and sufficient $0.15 \mathrm{M} \mathrm{NaCl}$ was added tc bring the powder into solution. This was centrifuged at $8,000 \mathrm{rpm}$ for 30 minutes and the supernatant fluid stored at $-20^{\circ} \mathrm{C}$. Before obtaining nasal secretions, a smear was gently taken from the nasal mucosa with a 


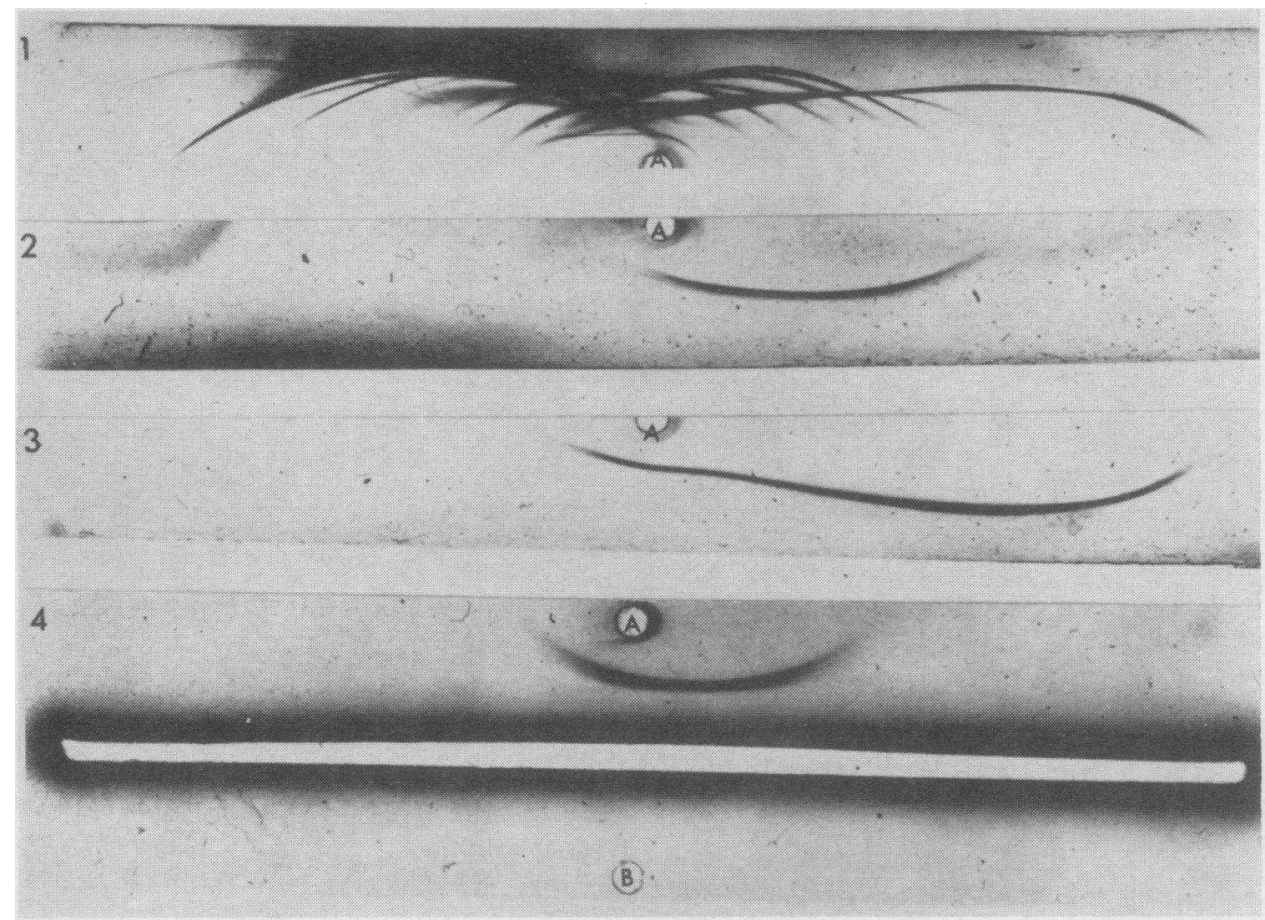

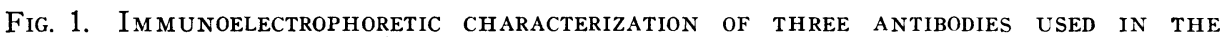
PRESENT STUDIES. Antiserum troughs are not shown except in part $4 . \mathrm{A}=$ normal human serum; $B=5 \%$ serum $7 \mathrm{~S} \gamma_{2}$-globulin; $1=$ horse antihuman serum; 2 and $4=$ goat antihuman $\gamma_{1 \mathrm{~A}}$-globulin used for immunoplates; $3=$ antihuman $7 \mathrm{~S} \gamma_{2}$-globulin.

cotton swab and the material applied to microscope slides. The preparations were stained with Wright's stain. No red blood cells were observed in the mucosal smears of any of the volunteers. The nasal secretions of three subjects contained large numbers of polymorphonuclear leukocytes and were not used.

Immunoelectrophoresis. The micromethod of Scheidegger (19) was employed with $1 \%$ agar in barbital buffer $\mathrm{pH} 8.2(\mu 0.05)$. After the precipitin lines appeared to be at optimal intensity ( 24 to 72 hours), the agar was washed in $0.15 \mathrm{M} \mathrm{NaCl}$, and the precipitin lines were stained with Ponceau S.

Double diffusion in agar gel. The technique of Ouchterlony was used (20). In some instances, a micromethod was employed as previously described (9).

Antisera. ${ }^{1}$ Goat antihuman $7 \mathrm{~S} \gamma$-globulin, no. G1063A and no. 6173-9P71562; horse antihuman $\beta_{2}$-macroglobulin, no. H137 2-63; goat antihuman $\beta_{2}$-macroglobulin, no. G37-98/3-3163; horse antihuman serum, no. H76138 53062; horse anti-F II no. H205PABS; and goat antihuman $\beta_{2 \mathrm{~A}}\left(\gamma_{1 \mathrm{~A}}\right)$-globulin, no. G206-7ABS-3163 were used. Before use, the last antiserum was adsorbed with normal human cord serum, as well as with a serum that lacked $\gamma_{1 \mathrm{~A}}$-globulin obtained from a patient with dysgammaglobulinemia. A single precipitin line resulted

\footnotetext{
1 Purchased from Hyland Laboratories, Los Angeles, Calif.
}

from the reaction of the adsorbed anti- $\beta_{2 \mathrm{~A}}$ antiserum with normal human serum [Figure 1 (4) and Figure 2 (3)].

Analytical ultracentrifugation. A Spinco model E ultracentrifuge equipped with Schlieren and Rayleigh optics was used. Sedimentation velocity experiments were performed at $52,640 \mathrm{rpm}$ in a double-sector $12-\mathrm{mm}$ cell with rotor temperature maintained at $20^{\circ} \mathrm{C}$. Measurements of the photographic plates were made in a Nikon microcomparator.

Electrophoresis. Cellulose acetate strips were used with a barbital buffer at $\mathrm{pH} 8.6(\mu$ 0.075). After drying, the strips were stained with Ponceau S. Starch-block electrophoresis was performed in borate buffer at $\mathrm{pH} 8.6$ $(\mu 0.064)$. The separated proteins from serum or nasal secretions were eluted from $1-\mathrm{cm}$ segments of the blocks. Nasal secretion protein fractions with electrophoretic mobilities corresponding to those of individual serum proteins were pooled and dialyzed against distilled water. The fractions were lyophilized, resuspended in $0.15 \mathrm{M}$ $\mathrm{NaCl}$, and centrifuged at $8,000 \mathrm{rpm}$ for 30 minutes to remove insoluble starch granules. In some experiments, a polyvinyl chloride ${ }^{2}$ preparation was used instead of starch.

Quantitative estimation of proteins. Immunodiffusion : Initially, the technique described by Feinberg was used

\footnotetext{
2 Pevikon, C-870, Stockholms Superfosfat Fabriks Aktiebolag, Stockholm, Sweden.
} 


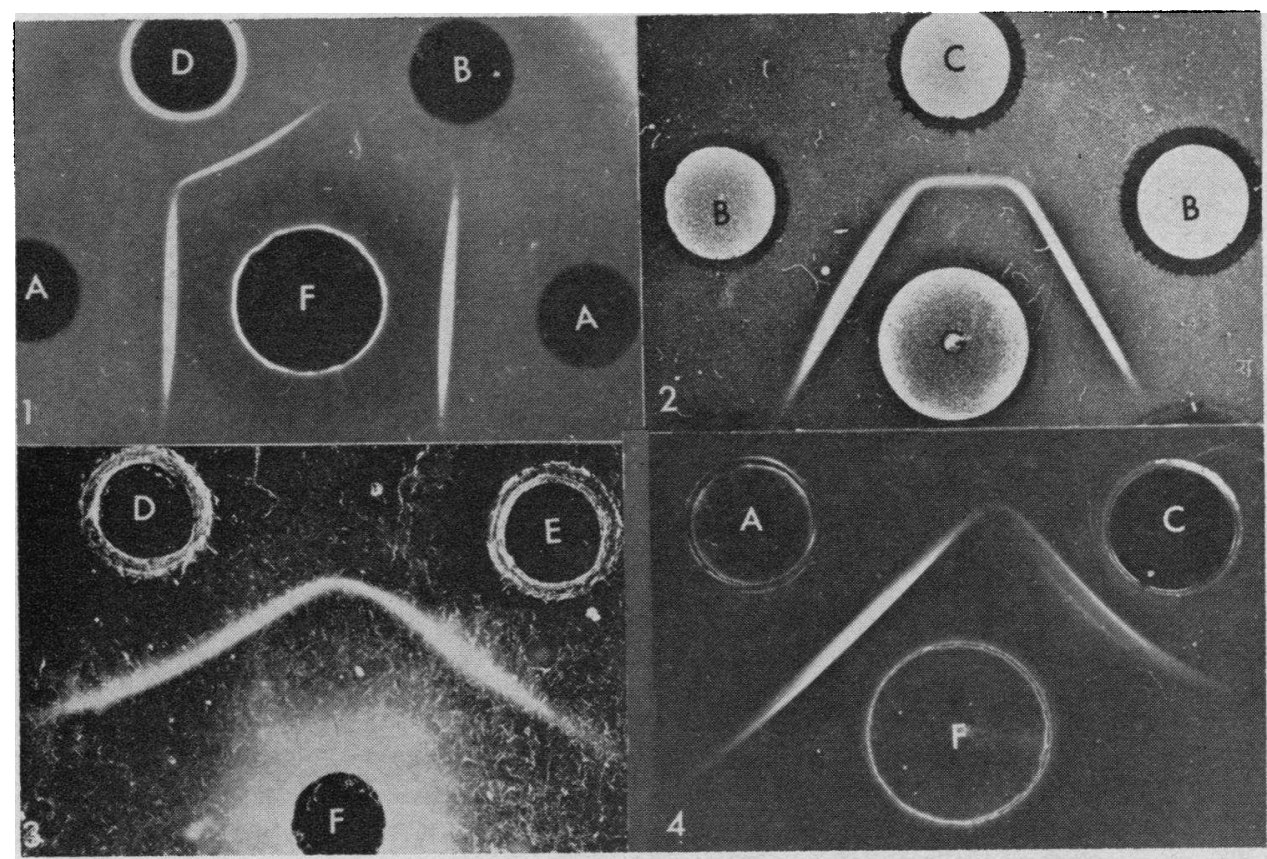

Fig. 2. Double diffusion in AGar Gel of PURIFIEd IMMUNe globulins ANd proteins of NASAL SECRETIONS. $A=$ purified $\gamma_{1 A}$-globulins from serum; $B=$ purified $7 \mathrm{~S} \boldsymbol{\gamma}_{2}$-globulins from serum; $C=$ Fraction I from starch block (see Figure 3 ) ; $D=$ normal nasal secretions; $E=$ normal human serum; $F=$ goat anti- $\gamma_{1 \Delta}-$ globulins $; G=$ goat antihuman $7 \mathrm{~S} \gamma_{2}$-globulin [same as used in Figure 5 (1)].

(21). The values obtained with the Hyland immunoplates $^{1}$ for $\beta_{3 \mathrm{~A}}$ - and $7 \mathrm{~S} \gamma$-globulins agreed very well with those obtained with the Feinberg method and thus were substituted in later studies. The results of the reaction between the antisera used in the immunoplates and normal human serum are shown in Figure $1(2,3)$. A single precipitin line was noted in each instance. Serial 2-fold dilutions were made of sera from 1:2 through $1: 16$, and a sample of the undiluted serum and each dilution was placed in a well of the immunoplates. The corresponding nasal secretions were placed undiluted in alternate wells on the same plates. After incubation for 4 to 6 hours at $37^{\circ} \mathrm{C}$ in the case of the antihuman $\gamma$-globulin plate, and for 16 hours at room temperature for the antihuman $\gamma_{1 \Delta}$ plate, the diameter of the precipitin rings was measured for each of the serum dilutions. The results were plotted on semilogarithmic paper, the log scale representing the percentage of the total serum protein in the sample (e.g., the undiluted serum represented $100 \%, 1: 2$ dilution, $50 \%$, etc.) and the linear scale, the diameter of the zones. In this manner a straight line was obtained, and the zone diameters about the well of nasal secretion were applied to the standard curve to obtain the relative concentration of specific protein in the sample. By using the values for the total protein in the serum (average, $8.1 \%$; range, $7.9 \%$ to $8.9 \%$ ) and samples of nasal secretions (average, $0.31 \%$; range, $0.1 \%$ to $0.5 \%$ ), the ratio $\mathrm{N} / \mathrm{S}$ of the total $\gamma_{2}$ globulins and $\gamma_{14}$-globulins in the nasal secretions to their concentrations in the corresponding serum was calculated from the formula:

$$
\frac{\mathrm{N}}{\mathrm{S}}=\frac{\mathrm{C}_{\mathrm{nig}}}{\mathrm{C}_{\mathrm{tnp}}} \times \frac{\mathrm{C}_{\mathrm{tsp}}}{\mathrm{C}_{\mathrm{sig}}}
$$

where $C_{n 1 g}=$ nasal secretion immune globulin concentration (immunoplate), $\mathrm{C}_{\mathrm{sig}}=$ serum immune globulin concentration (immunoplate), $C_{\text {tnp }}=$ total nasal secretion protein concentration (refractometry), and $\mathrm{C}_{\mathrm{tsp}}=$ total serum protein concentration (refractometry).

Refractometry. Protein concentrations were determined on isotonic solutions by using a commercial refractometer designed for serum protein determinations. ${ }^{3}$ This method was used because it is nondestructive to the material measured and does not depend on the individual nature of the proteins measured $(22,23)$. The results obtained using refractometry agreed satisfactorily with those obtained in separate experiments using the microKjeldahl technique.

Passive transfer. Reaginic activity in serum and nasal secretions was determined by the Prausnitz-Kustner test (24). $0.25 \mathrm{ml}$ of the serum or concentrated nasal secretion solution was injected intradermally through a Swinny filter adapter containing a $0.47-\mu$ Millipore filter. Twenty-four to 48 hours later, the site was challenged with $0.05 \mathrm{ml}$ of a concentrated and purified orchard grass

3 Atago protometer, National Instrument Co., Baltimore, Md. 


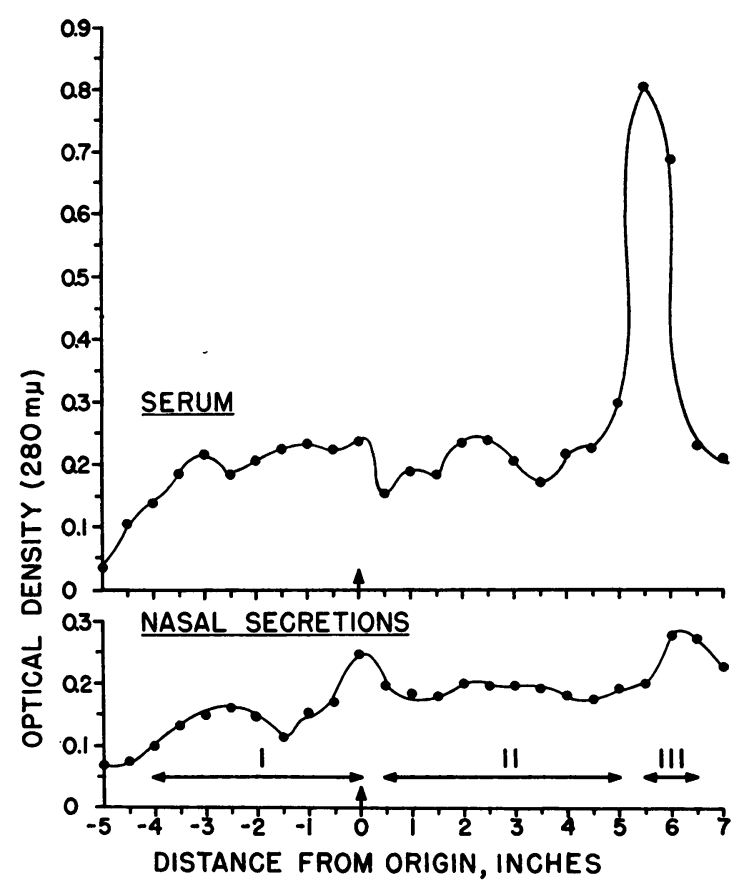

Fig. 3. Separation by Starch block electrophoresis OF NORMAL HUMAN SERUM AND DIALYZED, LYOPHILIZED, NORMAL HUMAN NASAL SECRETIONS POOLED From 15 SCBJECTS.

allergen dissolved in $0.15 \mathrm{M} \mathrm{NaCl}$. [The antigen was a $16 \mathrm{mg}$ per $\mathrm{ml}$ isotonic solution of an orchard grass pollen preparation purified by ammonium sulphate precipitation to remove hemagglutinating antigen followed by ethanol precipitation of inert ingredients (25)]. The reactions were graded from negative (control) to $4+$ $(1+, 5-\mathrm{mm}$ wheal with erythema; $2+, 10-\mathrm{mm}$ wheal with erythema; $3+, 15-\mathrm{mm}$ wheal with pseudopods and erythema, and $4+, 20-\mathrm{mm}$ wheal with pseudopods and erythema).

Immunization. Volunteers were immunized with either $0.5 \mathrm{ml}$ of tetanus toxoid ${ }^{4}$ or diphtheria toxoid. ${ }^{5}$ Blood and nasal secretions were obtained from each person just before and 14 days after immunization. In cases of primary immunization, blood and nasal secretions were collected again at 30 days. Sera were obtained also from individuals with high antistreptococcal antibody titers due to natural infection.

Hemagglutination. Human, group $\mathrm{O}$, Rh-negative, red blood cells were used. The hemagglutination tests were performed as described for type specific streptococcal antibody by Vosti and Rantz (26) and for tetanus and diphtheria antibodies as described by Levine, Wy-

\footnotetext{
4 Cutter lot G 4822, Cutter Laboratories, Berkeley, Calif.

5 Purified diphtheria toxoid lot no. KP 59 A, Massachusetts Department of Public Health, Division of Biologic Laboratories, Boston, Mass.
}

man, Broderick, and Ipsen (27). Four volumes of a $1 / 320$ dilution of the stock semipurified $M$ protein or of $37.5 \mathrm{Lf}$ (the amount of toxin that produces optimal flocculation with $1 \mathrm{U}$ of antitoxin) of tetanus or diphtheria toxoid was incubated for 15 minutes at room temperature with 1 vol of tanned cells. Lyophilized nasal secretions used for determination of hemagglutinins were reconstituted in a volume of $0.5 \mathrm{ml}$ of $1 / 100$ normal rabbit serum, and each specimen was adsorbed with packed human type $O$ red blood cells (ratio, 1:2) to remove nonspecific hemagglutinins. Twofold dilutions of the serum or nasal secretions to be tested were made in $1 \%$ rabbit serum that had been adsorbed with human type $\mathrm{O}$ red blood cells. The sensitized cells were added, and the test was read by the pattern technique after incubation at room temperature for 2 hours (28). The agglutination patterns obtained with nasal secretions appeared the same as those with serum and ranged from folded edges and matting $(4+)$ through a granular carpet $(3+)$ and varying ring sizes $(2+$ to \pm$)$. The titer was read as the reciprocal of the last dilution giving a $3+$ or greater reaction.

Hemagglutination inhibition was performed using a $1: 10$ dilution of the stock tetanus antigen $(1,250 \mathrm{Lf})$ or of the undiluted streptococcal antigens. Before the addition of sensitized cells, $0.05 \mathrm{ml}$ of the diluted antigen was added to each tube of the diluted specimen of serum and nasal secretion, and the mixtures were incubated at room temperature for 30 minutes.

Preparation of protcin fractions. $\gamma_{1 \mathrm{~A}}$-Globulins were separated as follows. To 1 vol of serum was added 1 t vol of saturated ammonium sulfate. The precipitate was removed by centrifugation, dissolved, and dialyzed against distilled water. After removal of the euglobulin precipitate by centrifugation, the supernatant fluid was further processed by a modification of the zinc precipitation technique of Heremans (29). An equal volume of $0.1 \mathrm{M}$ $\mathrm{ZnSO}_{4}$ was added to the supernatant fluid and the $\mathrm{pH}$ immediately adjusted to 6.95 with aqueous sodium carbonate (saturated). After standing at room temperature for 1 hour, the precipitate was removed by centrifugation. The supernatant fluid was concentrated by the addition of $1: \mathrm{vol}$ of ammonium sulfate and the light precipitate removed by centrifugation and dissolved in 0.15 $\mathrm{M} \mathrm{NaCl}$. This preparation was placed on a column of Sephadex G-100 $(4 \times 120 \mathrm{~cm})$ and eluted with $0.15 \mathrm{M}$ $\mathrm{NaCl}$. The optical density of the eluates at $254 \mathrm{~m} \mu$ was recorded directly. Contents of tubes comprising portions of the elution patterns within each peak were combined, dialyzed against distilled water, and lyophilized. The resulting powders were resuspended in small volumes of $0.15 \mathrm{M} \mathrm{NaCl}$. Each fraction was studied for antigenic purity by immunoelectrophoresis and double diffusion in agar. The material from the first peak off the G-100 column contained the $\gamma_{1 \mathrm{~A}}$-globulins.

$7 \mathrm{~S} \gamma$-globulins were prepared by chromatography of Cutter poliomyelitis immune globulin lot no. E 3217 on DEAE cellulose in phosphate buffer, $0.0175 \mathrm{M}, \mathrm{pH} 6.3$.

Urinary $\gamma$-globulins and albumin were prepared as previously described (30). 

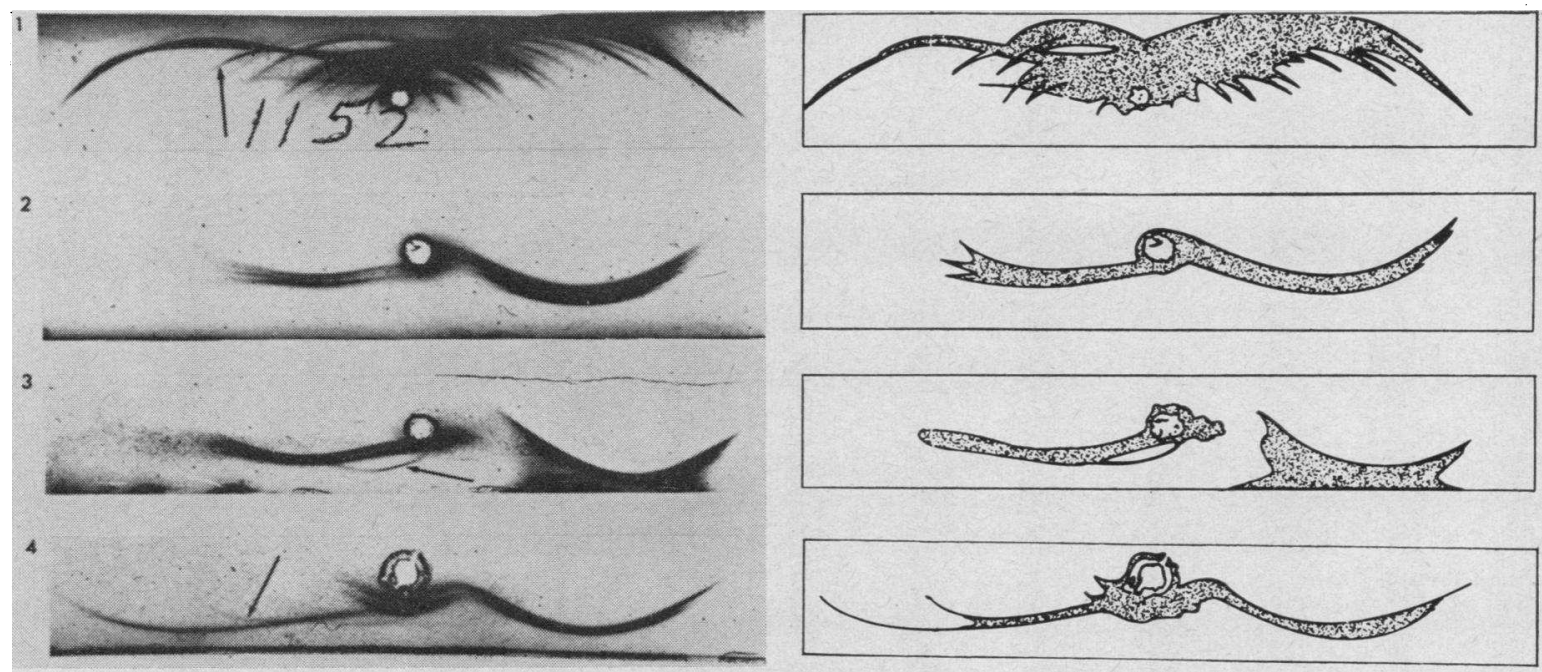

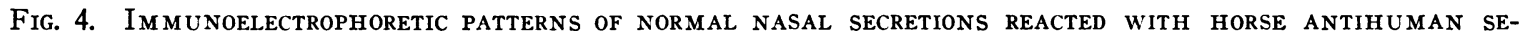
RUM. Right $=$ diagrammatic drawing of patterns shown on left. $1=$ normal human serum (arrow points to $\gamma_{1 A^{-}}$ globulin line) $; 2,3,4=$ nasal secretions (see text). Arrow in 1 and 4 points to $\gamma_{1 \mathrm{~A}}$-globulin arc; arrow in 3 points to an unidentified $\beta$-globulin arc.

Chromatography. Fractionation of nasal secretions was performed on columns of DEAE cellulose ${ }^{6}$ at $15^{\circ} \mathrm{C}$. Concentrated pools of nasal secretions were dialyzed against $0.0175 \mathrm{M}$ phosphate buffer at $\mathrm{pH}$ 6.3. The secretions were then placed on a column previously equilibrated with starting buffer until the effluent had a $\mathrm{pH}$ of 6.3. Columns were connected to a continuous flow ultraviolet absorption meter, and the optical density of the eluates at $254 \mathrm{~m} \mu$ was recorded directly. Elution with $0.0175 \mathrm{M}$ phosphate buffer was continued until there was no further ultraviolet absorption. Contents of tubes comprising the portion of the elution pattern within the peak were combined, dialyzed against distilled water, and lyophilized. The resulting powders were brought into solution with $0.15 \mathrm{M} \mathrm{NaCl}$.

\section{Results}

Electrophoresis. A representative pattern of the separation of the proteins of nasal secretions by starch block electrophoresis is shown in Figure 3. When the pool of concentrated eluates from the area corresponding to Fraction I of the starch block was analyzed by immunoelectrophoresis with an antiserum prepared against whole human serum, a single precipitin line appeared that corresponded to the area of electrophoretic mobility of the $\gamma_{1 \mathrm{~A}}$-globulins of normal serum run in parallel on the same slide. No precipitin line was present in the $\gamma_{2}$-globulin area of the Fraction I subjected to electrophoresis. However, analysis of the frac-

\footnotetext{
${ }^{6}$ Selectacel 70 standard grade, Brown Co., Berlin, N. H.
}

tion in an Ouchterlony plate with an antiserum prepared against $7 \mathrm{~S} \gamma_{2}$-globulins resulted in a precipitin line that gave a reaction of complete identity with serum $7 \mathrm{~S} \gamma_{2}$-globulins [Figure 2 (2)]. The anti-7 $\mathrm{S} \gamma_{2}$-globulin antiserum used in these studies did not cross-react with $\gamma_{1 \mathrm{~A}}$-globulins. A similar setup to that depicted in Figure 2 (2), but with an unadsorbed anti- $\gamma_{1 \mathrm{~A}}$ antiserum, resulted in a spur formation of the precipitin line formed by $\mathrm{C}$ over that formed by $\mathrm{B}$. When analyzed by immunoelectrophoresis with an antiserum to whole human serum, Fractions II and III each gave a single precipitin line corresponding in electrophoretic mobility to normal serum albumin.

Electrophoresis of the concentrated, pooled nasal secretions on cellulose acetate resulted in bands corresponding in mobilities to the albumin and $\beta$-globulins of normal human serum. In addition, three bands were present in the patterns of the nasal secretions that did not appear in those of serum. One occurred intermediate to the mobilities of the albumin and $\alpha_{1}$-globulins of serum; one between those of $\beta$ - and $\gamma$-globulins; and the third cathodic to the serum $\gamma$-globulins. A precipitin line did not result when this last slow-moving component was reacted in agar with an antiserum prepared against $7 \mathrm{~S} \gamma_{2}$-globulins.

Immunoelectrophoresis. Nasal secretions were obtained from 67 normal individuals. The mu- 


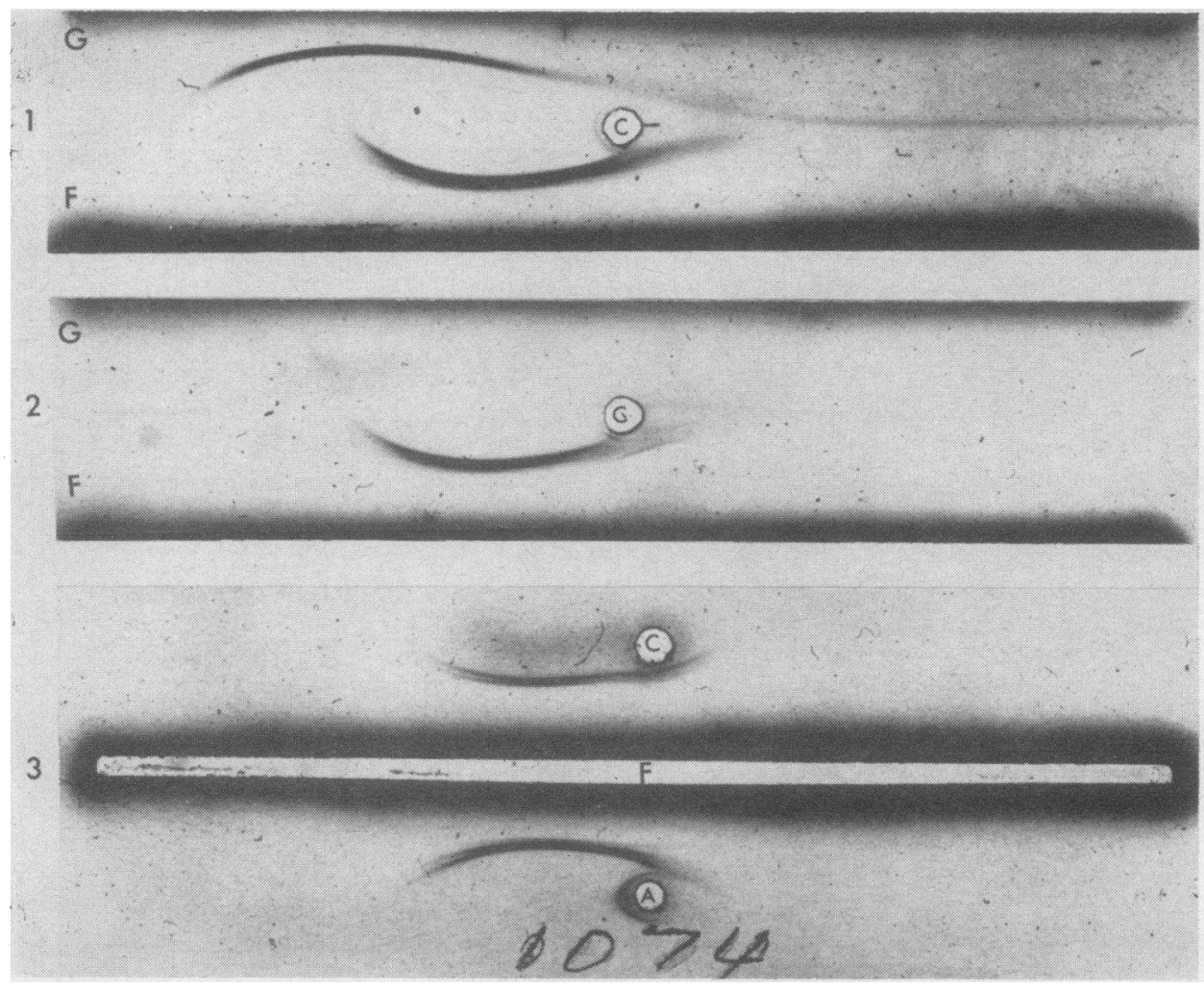

Fig. 5. IMMUNOELectrophoresis OF NORMAI. NASAL SECRETIONS. A = normal human serum; $\mathrm{C}=$ normal nasal secretions $; \mathrm{F}=$ goat anti- $\gamma_{1 \mathrm{~A}}$-globulins $; \mathrm{G}=$ goat antihuman $7 \mathrm{~S} \gamma_{2}$-globulins.

cosal smears from each of them showed a few squamous cells and a few polymorphonuclear leukocytes; no red cells were noted. Each sample was analyzed with antisera prepared against normal human serum, $7 \mathrm{~S} \gamma_{2}$-globulins, and $\gamma_{1 \mathrm{~A}}$-globulins. A typical pattern obtained when a sample of nasal secretions was reacted with an antihuman serum is shown in Figure 4 (2). The patterns of all 67 samples of nasal secretions showed precipitin lines that corresponded to the electrophoretic mobility of serum albumin and $\gamma_{1 \mathrm{~A}}$-globulins. In most cases, these two precipitin lines were the only ones visible. In 7 of the 67 patterns a precipitin line appeared also in the $\beta$ area, [Figure 4 (3) ], and in 4 of the 67 a clear precipitin line appeared in the area corresponding to the $7 \mathrm{~S} \gamma_{2}$ globulins of serum [Figure 4(4)]. The majority of specimens obtained from females gave very faint lines on immunoelectrophoresis when compared with the patterns of specimens obtained from males. Figure 5 depicts the results of the reaction between samples of nasal secretions, antihuman $7 \mathrm{~S} \gamma_{2}$-globulins, and antihuman $\gamma_{1 \mathrm{~A}}$-globu- lins. Those nasal secretions, which reacted with the anti-7 $\mathrm{S} \gamma_{2}$-globulin antiserum to give a precipitin line corresponding in electrophoretic mobility to the $\gamma_{2}$-globulins of serum, also contained $\gamma_{1 \mathrm{~A}}$-globulins [Figure 5 (1)]. Usually no precipitin arc was noted in the $\gamma_{2}$ region [Figure 5 (2)]. Figure 5 (3) shows the electrophoretic mobility of the $\gamma_{1 \mathrm{~A}}$-globulins of serum and nasal secretions to be similar.

No precipitin arc resulted from the reaction of any sample of nasal secretions with an antiserum to $\beta_{2 \mathrm{M}}$-globulins.

Nasal secretions were collected from 20 persons with histories of nasal allergy and documented evidence of immediate skin reactivity to allergens. The immunoelectrophoretic patterns obtained with the nasal secretions of these individuals did not appear to differ from those of normal persons. In three instances, a precipitin line was present that appeared to correspond to the line in the $\beta$-globulin area of the normal nasal secretions [Figure 4 (3)] ; in no instance was a precipitin line noted in the $\gamma_{2}$-globulin area. Even though 
there appeared to be little difference in the immunoelectrophoretic patterns of the nasal secretions of allergic and normal individuals, there was a marked difference in their nasal smears. Mucosal cells, polymorphonuclear leukocytes, and eosinophiles appeared more frequently in the smears of the allergic patients.

Double diffusion in agar. Although the majority of samples of nasal secretions failed to reveal $7 \mathrm{~S} \gamma_{2}$-globulins when analyzed by immunoelectrophoresis, all of them formed a precipitin line that gave a reaction of complete identity with serum $7 \mathrm{~S} \gamma_{2}$-globulins when analyzed by the Ouchterlony method. Figure 2 (1) shows the results of the reaction between normal nasal secretions and purified $\gamma_{1 \mathrm{~A}}$-globulins with an antiserum prepared against $\gamma_{1 \mathbf{A}}$-globulins. All samples gave a reaction of complete identity. In several patterns

TABLE I

Relative immune globulin quotients: nasal secretions to serum

\begin{tabular}{ccc}
\hline \hline Sample no. & $\gamma_{1 \mathrm{~A}}\left(\mathrm{~N} / \mathrm{S}^{*}\right)$ & Total $\gamma_{2}(\mathrm{~N} / \mathrm{S})$ \\
\hline 1 & 9.8 & 0.4 \\
2 & 6.5 & 1.2 \\
3 & 2.0 & 0.5 \\
4 & 4.0 & 0.5 \\
5 & 5.2 & 0.4 \\
6 & 6.1 & 0.9
\end{tabular}

${ }^{*} \mathrm{~N}=$ fraction of total nasal proteins; $\mathrm{S}=$ fraction of total serum proteins.

of the nasal secretions, a second precipitin line was noted between the major precipitin line and the antibody well. This second precipitin line was noted also with a $\gamma$-globulin preparation obtained by starch block electrophoresis of one of the pools of nasal secretions [Figure 2 (4)].

A reaction of complete identity occurred between the precipitin line formed by the $\gamma$-globulins of nasal secretions and the precipitin line formed nearest the well ( $7 \mathrm{~S} \gamma$-globulin line) containing urinary $\gamma$-globulins, when these antigens were reacted against an antiserum to $7 \mathrm{~S} \gamma_{2}$-globulins. Reactions of complete identity were also noted when an antiserum to human serum albumin was reacted in agar against serum, nasal secretions, and urinary albumin.

Ultracentrifugation. Ultracentrifugal analyses were performed on two pools of concentrated

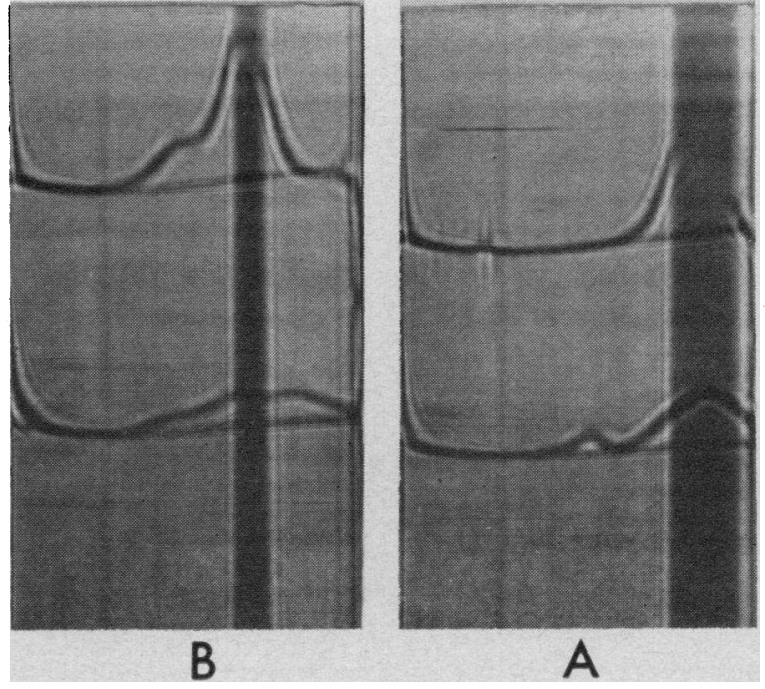

Fig. 6. Ultracentrifuge Patterns of NORMAL HUMAN SERUM (above) AND POOLED NORMAL NASAL SECRETions (below). Sedimentation from right to left. Pictures were taken at 48 minutes (A) and 96 minutes (B).

nasal secretions. One pool represented five normal individuals and the other eighteen. Figure 6 shows representative Schlieren diagrams obtained with the pool from the eighteen persons. Patterns obtained with both pools showed four peaks with $S_{20, w}$ values of $12.3,6.3,4.3$, and 2.4. Patterns obtained with the $\gamma$-globulins of nasal secretions that were separated by chromatography on DEAE cellulose resin revealed a major peak with an $S_{20, v 0}$ of 1.1 and a minor peak with an $S_{20, w}$ of 6.1. A similar Schlieren pattern was obtained with Fraction I from the starch block.

Quantitation of immune globulins. The concentrations of both $7 \mathrm{~S} \gamma_{2}$-globulins and $\gamma_{1 \mathrm{~A}}$-globulins in the proteins of nasal secretions from six normal individuals were compared with the total concentrations of these globulins in the proteins of corresponding sera obtained at the same time as the nasal secretions. The results are shown in Table I. Fractional $\gamma_{1 \mathrm{~A}}$-globulin concentrations in nasal secretions ranged from 2 to 10 times their fractional concentration in the corresponding serum. In nasal secretions, $\gamma_{2}$-globulins were usually present in lower fractional concentrations than in the corresponding serum.

Antibody studies. 1) Tetanus. Nasal secretions collected from 13 persons who had received booster doses of tetanus toxoid were analyzed for 
TABLE II

Tetanus hemagglutinins in sera and nasal secretions of three volunteers

\begin{tabular}{|c|c|c|c|c|c|c|c|}
\hline \multirow{2}{*}{$\begin{array}{l}\text { Specific } \\
\text { inhibitor }\end{array}$} & \multicolumn{3}{|c|}{ Serum no. } & \multicolumn{4}{|c|}{ Nasal secretion no. } \\
\hline & 1 & 4 & 5 & 1 & 4 & 5 & Pool* \\
\hline $\begin{array}{l}\text { Absent } \\
\text { Present }\end{array}$ & $\underset{20}{655,360 \dagger}$ & $\begin{array}{c}2,621,440 \\
\text { N.D. }\end{array}$ & $\begin{array}{c}1,310,720 \\
\text { N.D. }\end{array}$ & $\begin{array}{r}160 \\
10\end{array}$ & $\begin{array}{r}640 \\
40\end{array}$ & $\begin{array}{l}80 \\
10\end{array}$ & $\begin{array}{r}2,560 \\
<10\end{array}$ \\
\hline
\end{tabular}

* Concentrate of 15 samples.

$\dagger$ Reciprocal hemagglutinin titer.

$\ddagger$ Not done.

the presence of serum proteins by immunoelectrophoresis. The patterns did not differ from those of the normal volunteers. Seven samples of nasal secretions were pooled and reacted against tetanus toxoid in an Ouchterlony plate. The resulting single precipitin line gave a reaction of complete identity with that resulting from the reaction of the corresponding pool of serum with tetanus toxoid. The precipitating activity of another similar pool, separated by starch block electrophoresis, was found only in the $\gamma$-globulin fraction. The results of hemagglutination tests with the nasal secretions and the corresponding serum of three individuals are shown in Table II. Significant inhibition of hemagglutination resulted if serum or nasal secretions were incubated with antigen before addition of sensitized cells. Each of the remaining three specimens of nasal secretions and the corresponding sera were all found to have positive titers by hemagglutination.

2) Streptococcus. A comparison of type specific streptococcal hemagglutinating antibody in the serum and nasal secretions of a volunteer is shown in Table III. Specificity of the reaction was shown by the ability of the antigen to inhibit the reaction in both serum and nasal secretion. Antibodies were found in nasal secretions only when they were present in the corresponding serum.

TABLE III

Type specific streptococcal hemagglutinins in serum and nasal secretions of a volunteer

\begin{tabular}{llcr}
\hline & & \multicolumn{2}{c}{ Titer } \\
\cline { 3 - 4 } Test antigen & Inhibitor & Serum & $\begin{array}{c}\text { Nasal } \\
\text { secretion }\end{array}$ \\
\hline Type 17 & None & $5,120^{*}$ & 2,560 \\
Type 17 & Type 17 & $<10$ & 10 \\
Type 12 & None & $<10$ & $<10$ \\
\hline
\end{tabular}

* Reciprocal hemagglutinin titer.
3) Diphtheria. Control serum and nasal secretions were obtained from five adults. Two of these patients, who were shown to have levels of serum hemagglutinins to diphtheria toxoid in titers of $>1: 100,000$, had antibody in their nasal secretions. Of the remaining three subjects, two had serum titers of $<1: 64$, and one had no measurable titer at $1: 4$. All three had no antibody in their nasal secretions. After immunization, these three patients showed greatly increased titers of antibody in their serum, and antibody appeared in their nasal secretions. The antibody activity was found in the $\gamma$-globulin fraction obtained by starch block electrophoresis. Again, as with the other antigens, inhibition of hemagglutination could be accomplished by incubation of the serum or nasal secretions with the antigen before the addition of the sensitized red blood cells.

Passive transfer studies. Serum and nasal secretions were obtained from six individuals with known allergies and immediate skin hypersensitivity to grass pollen allergens. The nasal secretions were analyzed by immunoelectrophoresis, and the patterns of each showed precipitin lines only in the albumin and $\gamma_{1 \mathrm{~A}}$ areas. Similar specimens were collected from four persons without known allergy who did not react to an intradermal inoculation of grass pollen allergens. Recipients of passive transfer experiments met the same criteria as the latter group. Only serum and nasal secretions from allergic individuals caused a positive Prausnitz-Kustner reaction. However, one sample of nasal secretions from an allergic person failed to give a Prausnitz-Kustner reaction despite a $3+$ reaction elicited with corresponding serum. Except for the degree of intensity $(3+$ to $4+$ for serum and $1+$ to $3+$ for nasal secretions) reactions at the sites of the injected nasal secretions did not differ from sites prepared with serum. Heating serum or nasal secretions at $56^{\circ} \mathrm{C}$ for 2 hours destroyed their capacity to react in the Prausnitz-Kustner test.

\section{Discussion}

This study describes certain immunochemical and physicochemical properties of the $\gamma$-globulins present in normal human nasal secretions. These $\gamma$-globulins possess hemagglutinating, precipitating, and reagenic antibody activities. 


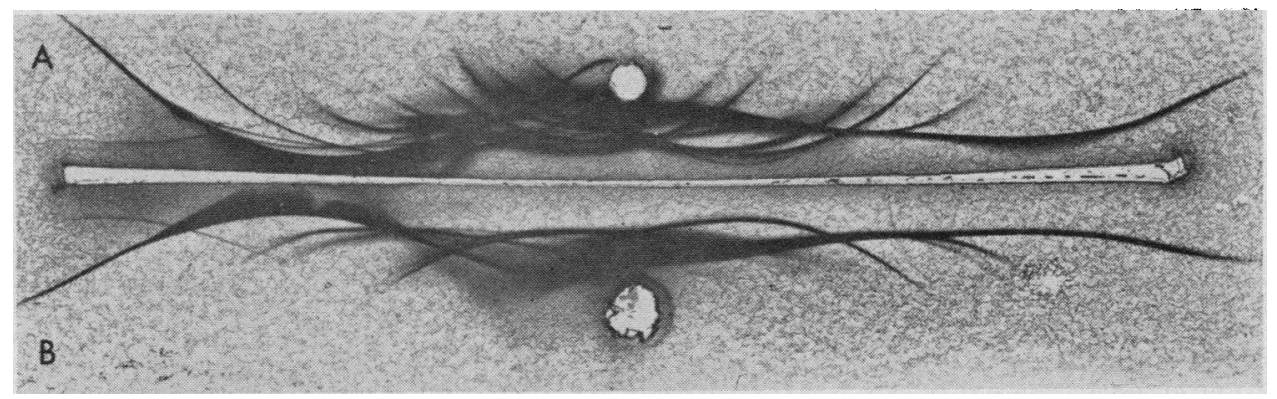

Fig. 7. IMMUNOELECTROPHORESis OF NASAL SECRETIONS OBTAINED With COTTON SOAKED IN $10 \%$

$\mathrm{NACL}_{\text {. }} \mathrm{A}=$ normal human serum; $\mathrm{B}=$ nasal secretions $;$ antiserum $=$ horse antihuman serum.

To obtain nasal secretions as they occur normally, special precautions were taken in the collection of the samples to prevent damage to the mucous membrane that might cause a leak of serum proteins. Collections of nasal secretions with cotton or gauze, either dry $(14,17,31)$ or soaked with $10 \%$ saline $(32)$, were not used because of the possibility of local irritation. Preliminary results in our laboratory with immunoelectrophoretic analyses of nasal secretions collected with cotton soaked in $10 \% \mathrm{NaCl}$ gave completely different results from those obtained from the same individuals using a $0.15 \mathrm{M} \mathrm{NaCl}$ wash as described in the present studies. The former method caused an outpouring of serum proteins (Figure 7) probably representing a response to local irritation and injury due to the foreign body or hypertonic solution, or both. Nasal secretions collected using such methods cannot be considered physiological, and the finding of antibodies in the secretions would not be surprising (32).

Analysis of normal nasal secretions by immunoelectrophoresis revealed $\gamma_{1 \mathrm{~A}}$-globulins and albumin to be the two serum proteins most commonly present. In some instances, $\gamma_{2}$-globulins and an unidentified $\beta$-globulin were also present. With the Ouchterlony method, $7 \mathrm{~S} \gamma_{2}$-globulins were shown to be present in all samples of nasal secretions despite the fact that the corresponding precipitin line was relatively uncommon on the immunoelectrophoretic patterns. The finding of a protein in nasal secretions more electropositive than serum $\gamma_{2}$-globulins on the cellulose acetate electrophoresis patterns was of interest in view of the previous observation of a protein of similar mobility in normal human urine (30). This may be lysozyme, which is known to migrate cathodic to serum $\gamma$-globulin (33). Immunodiffusion patterns obtained with nasal secretions of allergic persons did not appear to differ significantly from those of normal individuals despite the fact that the former often contained many eosinophils on cytological examination.

The results of the quantitative analyses indicate that the $\gamma$-globulins in nasal secretions are primarily composed of the $\gamma_{1 \mathrm{~A}}$ component. Thus, a selective mechanism is probably involved in the delivery of this serum protein into the nasal secretions. Tomasi and Zigelbaum (34) recently reported finding relatively high concentrations of $\gamma_{1 \mathrm{~A}}$-globulins in other body fluids when compared to the corresponding sera and have suggested that factors in addition to simple transudation from serum are in operation. The lack of other $\alpha$ - and $\beta$-globulins in nasal secretions, in amounts which can be discerned by immunoelectrophoresis, is difficult to explain. This absence cannot be explained simply by differences in molecular weight of the serum proteins, since a portion of the purified $\gamma$-globulins obtained from nasal secretions have an $S_{20, w}$ of at least 6.1. Anderson, Riff, and Jackson (18), in studies of nasal secretions collected during a common cold, noted that 10 to $20 \%$ of individuals tested before challenge with the virus had $\gamma$-globulins in addition to albumin in their nasal secretions. The authors stated that these specimens either contained hemoglobin or were taken from subjects who demonstrated polymorphonuclear leukocytes on smears taken at the time nasal washings were done. They concluded that $\gamma$-globulins are absent in normal nasal secretions. The protein concentration in the samples they analyzed was constant at $3 \mathrm{~g}$ per $100 \mathrm{ml}$, a value far in excess of the concentration of most of 
the samples analyzed in the present study. The reason for the differences in results between the present study and those of Anderson and associates is not known.

Studies using double diffusion in agar gel failed to reveal a pattern suggestive of low molecular weight $\gamma_{2}$-globulins in nasal secretions. However, analytical ultracentrifugal studies of the purified $\gamma$-globulins of normal nasal secretions revealed a slow sedimenting component with an $S_{20, w}$ of 1.1 in addition to the $6.1 \mathrm{~S}$ component. These sedimentation coefficients did not vary significantly in samples prepared from starch block electrophoresis or chromatography on DEAE cellulose. Although the low molecular weight component represents the major fraction of the purified $\gamma$-globulins, it may be in too low concentration in the preparations to give a visible precipitin arc. In the case of urinary $\gamma$-globulins, the $7 \mathrm{~S}$ fraction, which constituted $10 \%$ or less of the total preparations, formed a much clearer precipitin line with the antibody than did the highly concentrated low molecular weight fraction (30). In some instances, the reaction of $\gamma$-globulins of total nasal secretions with an antiserum prepared against $\gamma_{1 \mathrm{~A}}$-globulins resulted in 2 precipitin lines. Whether each precipitin line represents a species of molecule of different molecular weight or simply antigenic heterogeneity, or both, is not known.

The presence of antibacterial antibodies in normal nasal secretions suggests that the secretions may play an important role in host defense against bacteria. The occurrence of carriers of diphtheria bacilli and of streptococci may be influenced by the presence or absence of antibodies in secretions from the nasal and nasopharyngeal mucosae. The studies by MacLeod, Hodges, Heidelberger, and Bernhard (35) indirectly suggest such an active role of nasopharyngeal secretions as a protective mechanism against the carrier state of pneumococci. Immunization of humans with a variety of capsular polysaccharides of pneumococcus significantly lowered the carrier rate for those pneumococcal types as compared with controls.

The precipitating and hemagglutinating antibody activity was noted in the samples of whole nasal secretions as well as in the preparations of total $\gamma$-globulins. The small amounts of $\gamma_{2}$-globulins present in the secretions could be responsible for the antibody activities. Whether or not the $\gamma_{1 \mathrm{~A}}$-globulin fraction of the total $\gamma$-globulins contained antibody was not determined in this study. Of interest is the recent report of Heremans, Vaerman, and Vaerman (36) that described antibody activity to diphtheria in the $\gamma_{1 \mathrm{~A}}$-globulin fraction of the serum of a subject vaccinated with diphtheria toxoid.

Reagenic antibodies have been shown recently to reside, at least in part, in the $\gamma_{1 \mathbf{A}}$-globulin fraction of the serum immune-globulins (37). Because of the limited amounts of material, the protein fraction of the nasal secretions that contain reagenic activity was not identified. The presence of local reagenic antibodies in the nasal secretions may be one of the host's first lines of defense against inhaled allergens. Clinical symptoms that follow such inhalation may be due to the release of histamine as a result of the reaction between allergen and reagin. That reagin-bearing serum is capable of sensitizing nasal mucous membranes was shown experimentally by Sherman, Kaplan, and Walzer (38), who elicited reactions at the sensitized sites (inferior turbinate and septum) by topical application of the allergen. The liberation of histamine into the blood plasma has been shown after incubation of whole blood of a clinically sensitive individual with ragweed antigen $(39,40)$. An analogous situation may take place in the nose. Mast cells in addition to goblet cells and eosinophiles are seen in significant numbers on cytological examination of nasal secretions obtained from allergic persons (41), whereas mast cells are infrequently seen in most nasal smears from persons with colds or chronic infections. When the increase in number of mast cells is marked, the allergic reaction is usually severe. The prominent role of the mast cell in the allergic nasal response may be to release histamine (42). Thus, the finding of relatively high concentrations of $\gamma_{1 \mathbf{A}}$-globulins in association with reagin activity in the nasal secretions may be more than of theoretical interest and may lead to a better understanding of the mechanisms of nasal allergy.

\section{Summary}

Serum proteins and antibody activities were found in nasal secretions of normal and allergic individuals. The serum proteins in highest con- 
centrations were $\gamma_{1 \mathrm{~A}}$-globulins and albumin. $\gamma_{2}-$ Globulins were present in all specimens but in lower concentrations. Antibody activity to tetanus and diphtheria toxoids and streptococcal $\mathrm{M}$ protein was found in nasal secretions of normal volunteers whose sera showed high titers to the same antigens. Reagenic antibody activity was demonstrated in the nasal secretions of allergic individuals but not in those of nonallergic persons. The possible role of nasal secretions in host immunity and nasal allergy is discussed.

\section{Acknowledgments}

We acknowledge the assistance of Dr. William D. McKee, who examined the allergic patients, and the technical assistance of Miss Dorothy Williams.

\section{References}

1. Remington, J. S., and K. L. Vosti. Immunochemical studies of human nasal secretions. Clin. Res. 1964, 12, 111.

2. Straus, E. K. Occurrence of antibody in human vaginal mucous. Proc. Soc. exp. Biol. (N. Y.) 1961, 106, 617.

3. Anzai, T., J. Ibayashi, H. Aldrich, and C. M. Carpenter. Immunochemical study of vaginal secretion. I. Detection of serum and non-serum protein components in normal vaginal secretion. Proc. Soc. exp. Biol. (N. Y.) 1963, 113, 54.

4. Ellison, S. A., P. A. Mashimo, and I. D. Mandel. Immunochemical studies of human saliva. I. The demonstration of serum proteins in whole and parotid saliva. J. dent. Res. 1960, 39, 892.

5. Kraus, F. W., and J. Konno. Antibodies in saliva. Ann. N. Y. Acad. Sci. 1963, 106, 311.

6. Holman, H., W. F. Nickel, Jr., and M. H. Sleisenger. Hypoproteinemia antedating intestinal lesions, and possibly due to excessive serum protein loss into the intestine. Amer. J. Med. 1959, 27, 963.

7. Barnes, G. W., W. A. Soanes, L. Mamrod, M. J. Gonder, and S. Shulman. Immunologic properties of human prostatic fluid. J. Lab. clin. Med. 1963, 61, 578.

8. Lerner, A. M., J. S. Remington, and M. Finland. Neutralizing antibody to polioviruses in normal human urine. J. clin. Invest. 1962, 41, 805.

9. Remington, J. S., and M. Finland. Precipitating antibody in normal human urine. Proc. Soc. exp. Biol. (N. Y.) 1961, 107, 765.

10. Burrows, W., and I. Havens. Studies on immunity to Asiatic cholera. V. The absorption of immune globulin from the bowel and its excretion in the urine and feces of experimental animals and human volunteers. J. infect. Dis. 1948, 82, 231.

11. Lipton, M. M., and A. J. Steigman. Human coproantibody against polioviruses. J. infect. Dis. 1963 , $112,57$.

12. Amoss, H. L., and E. Taylor. Neutralization of the virus of poliomyelitis by nasal washings. J. exp. Med. 1917, 25, 507 .

13. Howitt, B. F. Relationship between nasal and humoral antipoliomyelitic substances. J. infect. Dis. 1937, 60, 113.

14. Burnet, F. M., D. Lush, and A. V. Jackson. A virusinactivating agent from human nasal secretion. Brit. J. exp. Path. 1939, $20,377$.

15. Francis, T., Jr., and I. J. Brightman. Virus-inactivating capacity of nasal secretions in the acute and convalescent stages of influenza. Proc. Soc. exp. Biol. (N. Y.) 1941, 48, 116.

16. Francis, T., Jr., H. E. Pearson, E. R. Sullivan, and P. M. Brown. The effect of subcutaneous vaccination with influenza virus upon the virus-inactivating capacity of nasal secretions. Amer. J. Hyg. 1943, 37, 294.

17. Bell, E. J. The relationship between the antipoliomyelitic properties of human nasopharyngeal secretions and blood serums. Amer. J. Hyg. 1948, 47, 351 .

18. Anderson, T. O., L. J. M. Riff, and G. G. Jackson. Immunoelectrophoresis of nasal secretions collected during a common cold: observations which suggest a mechanism of seroimmunity in viral respiratory infections. J. Immunol. 1962, 89, 691.

19. Scheidegger, J. J. Une micro-méthode de l'immunoélectrophorese. Int. Arch. Allergy 1955, 7, 103.

20. Ouchterlony, O. Antigen antibody reactions in gels. IV. Types of reactions in coordinated systems of diffusion. Acta path. microbiol. scand. 1953, 32, 231.

21. Feinberg, J. G. Identification, discrimination, and quantification in Ouchterlony gel plates. Int. Arch. Allergy 1957, 11, 129.

22. Glover, F. A., and J. D. S. Goulden. Relationship between refractive index and concentration of solutions. Nature (Lond.) 1963, 200, 1165.

23. Doty, P., and J. T. Edsall. Light scattering in protein solutions in Advances in Protein Chemistry, M. L. Anson, J. T. Edsall, and K. Bailey, Eds. New York, Academic Press, 1951, vol. 6, p. 54.

24. Prausnitz, C., and H. Kustner. Studien uber die uberempfindlichkeit. Zbl. Bakt., I. Abt. Orig. 1921, 86, 160.

25. Lietze, A. Calif. Med., in press.

26. Vosti, K. L., and L. A. Rantz. The measurement of type- and non-type specific group A hemolytic streptococcal antibody with an hemagglutination technique. J. Immunol. 1964, 92, 185.

27. Levine, L., L. Wyman, E. J. Broderick, and J. Ipsen, $\mathrm{Jr}$. A field study in triple immunization (diph- 
theria, pertussis, tetanus). Estimation of three antibodies in infant sera from a single heel puncture using agglutination techniques. J. Pediat. 1960, 57, 836.

28. Salk, J. E. A simplified procedure for titrating hemagglutinating capacity of influenza virus and the corresponding antibody. J. Immunol. 1944, 49, 87.

29. Heremans, J. Les Globulines Sériques du Système Gamma. Leur Nature et Leur Pathologie. Brussels, Arscia, 1960.

30. Merler, E., J. S. Remington, M. Finland, and D. Gitlin. Characterization of antibodies in normal human urine. J. clin. Invest. 1963, 42, 1340.

31. Francis, T., Jr. The inactivation of epidemic influenza virus by nasal secretions of human individuals. Science 1940, 91, 198.

32. Samter, M., and E. L. Becker. Ragweed reagins in nasal secretion. Proc. Soc. exp. Biol. (N. Y.) 1947, 65, 140.

33. Erickson, O. F., L. Feeney, and W. K. McEwen. Filter-paper electrophoresis of tears. II. Animal tears and the presence of "slow-moving lysozyme." Arch. Ophthal. 1956, 55, 800.

34. Tomasi, T. B., Jr., and S. Zigelbaum. The selective occurrence of $\gamma_{1 \mathrm{~A}}$-globulins in certain body fluids. J. clin. Invest. 1963, 42, 1552.

35. MacLeod, C. M., R. G. Hodges, M. Heidelberger, and W. G. Bernhard. Prevention of pneumococcal pneumonia by immunization with specific capsular polysaccharides. J. exp. Med. 1945, 82, 445.

36. Heremans, J. F., J. P. Vaerman, and C. Vaerman. Studies on the immune globulins of serum. II. A study of the distribution of anti-Brucella and anti-diphtheria antibody activities among $\gamma_{\mathbf{s s}^{-}} \gamma_{\mathbf{1}} \mathbf{M}^{-}$ and $\gamma_{1 \mathrm{~A}}$-globulin fractions. J. Immunol. 1963, 91, 11.

37. Fireman, P., W. E. Vannier, and H. C. Goodman. The association of skin-sensitizing antibody with the $\beta_{2 \mathrm{~A}}$-globulins in sera from ragweed-sensitive patients. J. exp. Med. 1963, 117, 603.

38. Sherman, H., C. Kaplan, and M. Walzer. Studies in mucous membrane hypersensitiveness. II. Passive local sensitization of the nasal mucous membrane. J. Allergy 1937, 9, 1.

39. VanArsdel, P. P., Jr., E. Middleton, Jr., W. B. Sherman, and H. Buchwald. A quantitative study on the in vitro release of histamine from leukocytes of atopic persons. J. Allergy 1958, 29, 429.

40. Noah, J. W., and A. Brand. Correlation of blood histamine release and skin test response to multiple antigens. J. Allergy 1955, 26, 385.

41. Bryan, W. T. K., and M. P. Bryan. Cytologic diagnosis in otolaryngology. Trans. Amer. Acad. Ophthal. Otolaryng. 1959, 63, 597.

42. Riley, J. F., and G. B. West. The presence of histamine in tissue mast cells. J. Physiol. (Lond.) 1953, 120, 528. 